\title{
Faculty Perceptions and Applications of the In-service Training Programs of the Association of Philippine Medical Colleges
}

\author{
Erlyn A. Sana, PhD, ${ }^{1}$ Melflor A. Atienza, MD, MHPEd, ${ }^{1}$ Ramon L. Arcadio, MD, MHPEd, DrHum, ${ }^{2}$ \\ Enrico B. Gruet, MD, ${ }^{3}$ Norman C. Gonzaga, MD, ${ }^{4}$ Remedios D. Chan, MD, MHPEd ${ }^{5}$ and Agnes D. Mejia, MD ${ }^{2}$

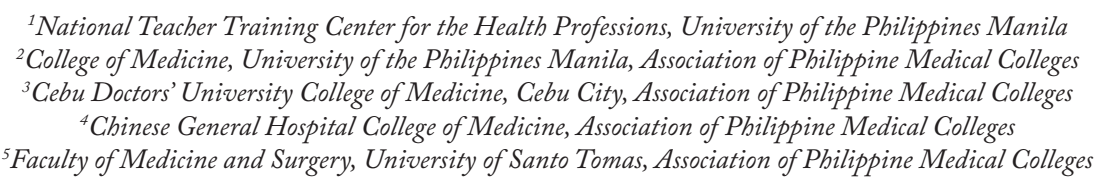

\section{ABSTRACT}

Objectives. The Association of Philippine Medical Colleges (APMC) responded to the global call for transformative learning by conducting a series of Faculty In-service Training. This study was commissioned to determine faculty trainees' perceptions of the program in terms of relevance, comprehensiveness, and quality. It also described their applications of the program in their delivery of instruction, assessment, organization, and management skills.

Methods. This is a sequential explanatory mixed-method research. The quantitative phase refers to the analysis of the rating scale accomplished by participants as feedback. The qualitative phase includes analysis of focus group discussion results and actual course syllabi used by selected participants, including medical schools' documents. Both data were integrated using a combination of descriptive statistics, measures of central tendency and dispersion, as well as joint displays.

Results. APMC conducted six in-service trainings from 2015 to 2018. Themes focused on medical teachers' roles as instructional designers, facilitators, assessors of learning, and as leaders and managers. Respondents perceived the programs as most relevant, comprehensive, and interesting. The syllabi, instructional resources, and assessment instruments and practices were consistent with the standards of the Commission on Higher Education. Medical teachers showed that they use innovative teaching and assessment strategies, and are dealing with medical education's continuous challenges.

Conclusion. Faculty participants perceived the APMC in-service training programs most favorably for capacitating them to enhance their teaching skills and inculcate the culture of quality in medical schools. APMC's training also reflects the organization's commitment to social accountability.

Key Words: Medical Education, Faculty In-service Training Program, Sequential Explanatory Mixed Methods Research, Faculty Development

Paper presented in the "Capacitating the Medical Faculty in Meeting the Standards of Medical Education." NTTCHP 45 th Founding Anniversary on January 27, 2020, at the Museum of a History of Ideas, University of the Philippines Manila, Philippines.

Paper presented in the Mixed Methods International Research Association Conference on December 4-6, 2019, at the Massey University, Wellington, New Zealand.

Paper presented in the "Capacitating the Medical Faculty in Meeting the Standards of Medical Education." Conference of the World Federation for Medical Education on April 7-10, 2019, held at Seoul, South Korea.

Corresponding author: Erlyn A. Sana, PhD

National Teacher Training Center for the Health Professions

University of the Philippines Manila

3F Joaquin Gonzales Building, Padre Faura corner Maria Orosa Streets,

Ermita, Manila 1000, Philippines

Email: easana1@up.edu.ph 


\section{INTRODUCTION}

\section{The Association of Philippine Medical Colleges}

The Association of Philippine Medical Colleges Foundation, Inc. (APMCFI or APMC) was founded in 1967. Its initial activities were to convince the schools to undergo voluntary accreditation and revision of core courses in the different disciplines to ensure quality medical education. ${ }^{1}$ At present, APMC serves as the umbrella organization of all government-recognized medical schools. It is represented in the Commission on Higher Education (CHED) Technical Committee for Medical Education (TCME), the government body designated to ensure quality medical education in the Philippines.

CHED issued Memorandum Order (CMO) 46 in 2012, calling higher education institutions (HEIs) to devote and focus on the production of professionals with high intellectual capability to maintain the institutions of the country but who can also produce new evidence, knowledge, and technology for continuous and sustainable development. CMO 46 calls on HEIs to pursue a culture of quality through the outcomebased education (OBE) quality assurance typology. ${ }^{2}$ This call culminated with the release of CMO 18, also known as the "Policies, Standards, and Guidelines for the Doctor of Medicine Program." 3 This set the minimum standards for the legal, curricular, instructional, administrative, and management of admission of students, deans, faculty, library, laboratory, training hospital, and the overall teachinglearning environment of medical schools in the country.

To capacitate the medical faculty in meeting the new standards set for medical education, APMC has been conducting a series of in-service training in two days of seminar-workshops on selected topics. The series of training was presented to the faculty participants as part of their continuing professional development (CPD) initiatives and meet the requirements of Republic Act (RA) 10912: The Continuing Professional Development Act of 2016. ${ }^{4}$ Furthermore, as faculty members given the responsibility to produce physicians who should meet the professional standards of RA No. 10968: An Act Institutionalizing the Philippine Qualifications Framework (PQF), their continuing education should be a part of their regular activities.

\section{Call for transformative learning and social accountability}

In 2010, three separate studies were done to evaluate how the world's medical schools' curricula evolved over the last 100 years. The Lancet Commission, Global Consensus on Social Accountability (GCSA) for Medical Schools, and the Carnegie Foundation commissioned the investigations to commemorate the centenary of the Flexnerian Curriculum. ${ }^{5-7}$ This curriculum, based on the recommendations given by Abraham Flexner in 1910, refers to the teaching of the basic medical sciences in the first two years, clinical sciences in the next two years, and actual clinical internship or direct patient care in the last year. Several innovations followed and were embraced by medical schools like the community-based, problem-, competency-, organ systems-, outcome-based and innovative tracks. However, the Flexnerian Curriculum remains to be the dominant design being used by most medical schools in the Philippines and the rest of the world. The three studies reveal that in general, the education and training of physicians became longer and more expensive but did not translate into improvements of the populations' health outcomes. The pattern of such education even reveals that health sciences schools train their students to work in a health system that no longer exists when they start professional practice. ${ }^{8}$ These findings apply to the Philippines because, until the present, it wants to promote primary care, public health, and use of health systems in the delivery of care. ${ }^{9}$ The basic health indicators, such as maternal and infant mortality rates, top ten causes of morbidity and mortality, control and prevention of communicable diseases, etc., remained the same over the last five decades. ${ }^{10}$

These developments paved the way for the World Health Organization (WHO) to call for a transformative scale-up of health professionals' education. This refers to "the sustainable expansion and reform of health professionals' education and training to increase the quantity, quality and relevance of these professionals, and in so doing strengthen the country health systems and improve population health outcomes."11 The three studies and WHO directly challenged medical schools to re-examine their vision against the measures of social accountability namely quality, equity, relevance, and cost-effectiveness. ${ }^{6}$

APMC joined this call and took it upon itself to also examine its raison d'etre. This study was commissioned to find out how the last four years of conducting in-service training for medical faculty has influenced their perspectives on teaching, actual course designing and delivery of instruction, as well as the assessment of student learning. Based on this study, APMC aims to determine its next courses of action to capacitate the faculty to transform medical education.

\section{Objectives}

This study describes how APMC capacitated the medical faculty to meet the basic standards in medical education. It also specifically:

1. Describes the series of CPDs conducted by APMC from 2015 to 2018

2. Determines the participants' perceived relevance, comprehensiveness, and quality of these CPD programs

3. Describes the perceived effects on participants' delivery of instruction, assessment, organization, and management skills. 


\section{METHODOLOGY}

\section{Research design}

This is an explanatory sequential mixed method design. This design is used because the study intends to describe the experience of all medical faculty who participated in the APMC in-service training programs comprehensively and holistically. These faculty members are APMC's major stakeholders, and their feedback is valuable to guide the institution to direct its succeeding programs. In this design, quantitative data are collected and analyzed first, and cognizant that such results only present a limited perspective, are followed up and reinforced by qualitative data. The final results or interpretation are derived from inferences provided by the two sources of quantitative and qualitative data. ${ }^{12,13}$ Table 1 presents this research design's schema.

The quantitative phase was completed in 2018. All participants in the seminar-workshops conducted within this period accomplished the feedback form. In 2019, as more medical schools and training hospitals sought the help of APMC to capacitate their faculty members and consultants, the need to examine how the programs have influenced the participants became imperative. The research team agreed to do more than just an evaluation of in-service training. The consensus was to review the immediate feedback accomplished by the participants and the actual outputs they turned in while the training was being conducted, compare these with actual syllabi, instructional resources, and instructional designs requested from them, as well as reconcile these with the online records available at their schools' official websites. These records reviews were also part of the questions verified during the series of focus group discussions (FGDs) conducted in 2019.

\section{Population and sampling procedures}

For the first and second specific objectives, the population referred to all participants in the 2015-2018 two-day seminar-workshops. There were 656 medical faculty members recorded as participants, and a complete enumeration was done. However, some participants were no longer around at the end of Day 1, Day 2, or both when the feedback forms were distributed. Therefore, the quantitative data were obtained from 476 and 352 participants in the first and second days, representing 71.65 and 71.11 percent response rates, respectively.

For the second and third specific objectives, respondents came from another set of 33 faculty members who attended the May to October 2019 in-service training programs. All these participants were also among those who attended the previous years' seminars and workshops. They were requested to participate in the FGDs and were chosen by convenience sampling. Since all workshops ended at 5:00 pm on both days, only those participants who gave consent and agreed to join the FGD were involved. Although no selection criteria were used in convenience sampling, the researchers made sure that participants represented those who attended any of the previous APMC workshops and that they came from three major geographic clusters of medical schools from Luzon, Visayas-Mindanao (combined), and the National Capital Region (NCR).

\section{Data collection procedures}

QUAN data were collected and analyzed from the accomplished feedback forms requested from all participants during the actual CPD programs. Participants used an agreement scale and are a standard feedback form among HEIs in the conduct of CPD programs as required by the Professional Regulation Commission's various councils.

Table 1. Explanatory Sequential Mixed Methods Design Used in the Study

\begin{tabular}{|c|c|c|c|}
\hline Phases of the study & Procedures used & Products obtained & Timeline \\
\hline Quantitative (QUAN) & $\begin{array}{l}\text { - Constructed the four-point agreement feedback form } \\
\text { scale with open-ended questions at the end } \\
\text { - All participants accomplished the scale }\end{array}$ & $\begin{array}{l}\text { - Accomplished feedback form with } \\
\text { mean ratings } \\
\text { - List of answers to open-ended questions }\end{array}$ & \multirow{2}{*}{$\begin{array}{l}\text { August } \\
2015 \text { to } \\
\text { November } \\
2018\end{array}$} \\
\hline QUAN data analysis & $\begin{array}{l}\text { - Means of each construct in the Feedback Form } \\
\text { - Frequency counts and percentage distributions } \\
\text { - Used Microsoft Excel } 2019\end{array}$ & $\begin{array}{l}\text { - Summary of accomplished feedback } \\
\text { using means and frequency counts } \\
\text { arranged in batches }\end{array}$ & \\
\hline Selection of groups & $\begin{array}{l}\text { - Many medical schools send the same participants } \\
\text { - Officials and resource persons look into how participants } \\
\text { make use of the in-service training } \\
\text { - Construction of focus group discussion (FGD) questions } \\
\text { and structure }\end{array}$ & $\begin{array}{l}\text { - Final schedule of FGD questions } \\
\text { constructed } \\
\text { - Structure of how to conduct the FGD } \\
\text { was finalized }\end{array}$ & \multirow[t]{2}{*}{$\begin{array}{l}\text { May } \\
2019 \text { to } \\
\text { September } \\
2019\end{array}$} \\
\hline Qualitative (QUAL) & $\begin{array}{l}\text { - Actual conduct of the FGDs with batches of participants } \\
\text { - Review of online records of medical schools } \\
\text { - Analysis of selected respondents' actual syllabi, } \\
\text { instructional designs, presentation slides }\end{array}$ & $\begin{array}{l}\text { - Recording of all FGDs conducted } \\
\text { - Photo documentation } \\
\text { - Collection of online records of schools } \\
\text { - Actual syllabi, instructional designs }\end{array}$ & \\
\hline QUAL data analysis & $\begin{array}{l}\text { - Transcribing all FGD proceedings } \\
\text { - Content analysis and identification of recurring themes } \\
\text { - Used NVivo } 12\end{array}$ & $\begin{array}{l}\text { - Codes and themes analyzed } \\
\text { - Compared with QUAN data }\end{array}$ & \multirow{2}{*}{$\begin{array}{l}\text { October } \\
2019 \text { to } \\
\text { January } \\
2020\end{array}$} \\
\hline Interpretation & - Presentation of separate QUAN \& QUAL data & - Integration of QUAN \& QUAL & \\
\hline
\end{tabular}


The tool was a four-point scale ranging from 1: Strongly Disagree, 2: Disagree, 3: Agree, and 4: Strongly Agree. The questions listed all the activities and sessions of the two-day seminar-workshops, and participants were requested to give their ratings on the following constructs:

1. Relevance to their work

2. Comprehensive discussion

3. Clear presentation

4. Interesting and interactive sessions

5. Presentation using appropriate visual aids

6. Adequate time

At the end of the questionnaire, spaces were provided for respondents to explain the factors that they perceived facilitated their learning and what they liked most and areas they think should be improved.

The qualitative (QUAL) phase involved collecting and analyzing participants' sample workshop outputs presented during the plenary sessions of the 2015-2018 in-service training. Actual course syllabi, tests, and other assessment instruments, handouts, and instructional resources shared by selected participants, which they used in their schools, were also reviewed. APMC also has a collection of these resources as part of its monitoring function for all medical schools; the updated versions were requested from respondents for this study. Secondary records available online were also used to reinforce the teachers' resources.

A total of five FGDs were conducted, participated by 6-12 participants each. There were two sessions done with NCR participants, one for Visayas-Mindanao group, and two from Luzon. The FGDs were conducted by the primary investigator and the first co-investigator, assisted by two university research personnel from the latter's institution. The FGDs were conducted from 30 to 45 minutes each. Questions focused on the participants' perceptions of the changing landscape of medical education and how the APMC can help them meet the standards set in CMO 18 and PQF.

\section{Analysis of data}

Quantitative (QUAN) data were analyzed using frequency counts, percentage distributions, means, and standard deviations using Microsoft Excel 2019. As results showed clearly negatively skewed distributions, the medians and interquartile range were computed to explain the degree of dispersion of participants' ratings. The CPD programs from 2015-2018 were also described according to their respective themes, dates conducted, several actual participants, objectives, and outputs produced by the participants. Furthermore, actual curriculum and instructional designs, resources like books and online articles, and assessments were analyzed repeatedly for common features. Since the schools' curriculum design surfaced to be the primary determinant of these selected resources, responses were grouped and analyzed according to these tracks. The same teachinglearning strategies, topics, and assessment measures that were enumerated in these documents were counted in terms of the number of their occurrence per theme and the FGDs.

Qualitative (QUAL) data composed of FGD transcriptions, instructional resources, syllabi, official records, and write-ups in the schools' official sites and samples of workshop outputs were reviewed iteratively, and content analyzed. Recurring issues, points, observations, questions, concerns, comments were noted and reconciled with the researchers' notes and memos. After multiple reviews, nodes were identified and counted for frequency using NVivo 10 until clear themes were formulated. The integration of QUAN and QUAL results were summarized using joint displays. These are presented in the form of tables and figures used to bring the data together to draw out new insights beyond what QUAN and QUAL data give. ${ }^{14}$ The central figures of joint displays usually refer to the main interpretation of findings representing the integration of both QUAN and QUAL data.

\section{RESULTS}

\section{QUAN Phase}

\section{Faculty Development Programs Conducted by APMC}

APMC conducted six CPD programs from 2015 to 2018. These programs were conducted three times to groups of faculty members from medical schools in Luzon, NCR, and Visayas-Mindanao (Vis-Min). A total of eighteen seminars-workshops were conducted for over four years. Table 2 presents the themes, titles, objectives, and actual outputs produced by the program participants. The principal investigator, the first and fifth co-investigators, served as resident instructional designers and resource persons. The rest of the researchers acted as facilitators. Each theme was conducted three times for schools in Luzon, Visayas and Mindanao, and the NCR. The number of participants ranged from 13 to 55 at a time.

\section{Participants' Perceptions of the CPD Programs}

The first seminar-workshop conducted in 2015 focused on the theme "Translating Program Outcomes into Course Designs." This was conducted at the time that the CMO 46 was already being carried out by all CHED technical committees, including the TCME. APMC conducted this training series at the Social Hall of the University of the Philippines-Philippine General Hospital in August, September, and October 2015. Participants were composed of 29 faculty from Luzon, 43 from Vis-Min, and 44 from $\mathrm{NCR}(\mathrm{n}=102)$. This two-day program was divided into 1 -hour inputs from resource persons who discussed the program outcomes expected from graduates of the Doctor of Medicine degree, how to translate these into actual course outcomes, how to organize these into subject matter according to the existing courses taught by participants, and basic principles of outcome-based assessment. There were two workshops and plenary sessions on the first two and last two inputs. 
In-service Training Programs for the Medical Faculty

Table 2. Seminar-Workshops Conducted by APMC from 2015-2018

Titles of Programs Objectives

Outputs of Participants

Theme 1: The medical faculty as a facilitator of learning

\begin{tabular}{|c|c|c|}
\hline $\begin{array}{l}\text { Translating } \\
\text { program outcomes } \\
\text { into course designs }\end{array}$ & $\begin{array}{l}\text { - Align course outcomes with program outcomes } \\
\text { - Organize course content to ensure achievement of outcomes } \\
\text { - Identify appropriate evaluation methods }\end{array}$ & $\begin{array}{l}\text { - Course outcomes } \\
\text { - Concept maps } \\
\text { - Course syllabi }\end{array}$ \\
\hline $\begin{array}{l}\text { Best-evidence } \\
\text { teaching strategies }\end{array}$ & $\begin{array}{l}\text { - Distinguish the basic features of best-evidence strategies following the OBE } \\
\text { curriculum and instructional design } \\
\text { - Given sample curricular scenarios, formulate appropriate technological pedagogical } \\
\text { content knowledge (TPACK) } \\
\text { - Deliver the TPACK using appropriate teaching-learning strategies }\end{array}$ & $\begin{array}{l}\text { - Course syllabi-with emphasis } \\
\text { on TPACK } \\
\text { - PBL trigger/case } \\
\text { - Demo of PBL }\end{array}$ \\
\hline $\begin{array}{l}\text { Mentoring for } \\
\text { medical schools }\end{array}$ & $\begin{array}{l}\text { - Develop an appropriate mentoring intervention plan } \\
\text { - Demonstrate the skills necessary for implementing the mentoring plan }\end{array}$ & $\begin{array}{l}\text { - Outcomes for a mentoring } \\
\text { program for their institution } \\
\text { - Mentoring skills }\end{array}$ \\
\hline \multicolumn{3}{|c|}{ Theme 2: The medical faculty as assessor of learner achievement } \\
\hline $\begin{array}{l}\text { Assessment of } \\
\text { student achievement }\end{array}$ & $\begin{array}{l}\text { - Construct an assessment blueprint based on intended outcomes } \\
\text { - Select appropriate tools to assess outcomes } \\
\text { - Formulate valid assessment tools }\end{array}$ & $\begin{array}{l}\text { - Test blueprints } \\
\text { - Selected response items }\end{array}$ \\
\hline $\begin{array}{l}\text { Quality Assurance } \\
\text { and Standard Setting }\end{array}$ & $\begin{array}{l}\text { - Formulate performance-based assessment blueprint based on program outcomes } \\
\text { - Construct valid assessment tools for formative and summative purposes } \\
\text { - Given sample assessment results, determine appropriate grading system } \\
\text { - Analyze own institution's performance based on recommended standards } \\
\text { - Formulate action plan }\end{array}$ & $\begin{array}{l}\text { - Assessment tools } \\
\text { - Analysis of one's institution's } \\
\text { performance and action plan }\end{array}$ \\
\hline \multicolumn{3}{|c|}{ Theme 3: The medical faculty as educational leaders and managers } \\
\hline $\begin{array}{l}\text { CPD for Academic } \\
\text { Executives of Medical } \\
\text { Schools }\end{array}$ & $\begin{array}{l}\text { - Align personal vision, mission, and goals, and educational philosophy with the } \\
\text { institution's } \\
\text { - Solve problems related to governance, HR, conflict, resource management, and } \\
\text { ethical practice } \\
\text { - Formulate a relevant organizational plan for continuous quality improvement }\end{array}$ & $\begin{array}{l}\text { - Reflection on VMG } \\
\text { - Situational analysis } \\
\text { - Logframe matrix }\end{array}$ \\
\hline
\end{tabular}

Table 3 presents the overall mean ratings, standard deviations (SD), medians, and interquartile range of the participants' scores. Results show homogeneous results as revealed by means very close to 4.0 and small values of $\mathrm{SDs}$. These figures indicate that the ratings were negatively skewed. For a more accurate estimate of the ratings, the medians and interquartile range were obtained. The median refers to the $50^{\text {th }}$ percentile of ratings made by the participants. The quartiles presented below refer to the $25^{\text {th }}$ (Q1) and $75^{\text {th }}(\mathrm{Q} 3)$ percentiles, and interquartile range (IQR): difference between Q3 and Q1. ${ }^{15}$ Figures indicate the homogeneity of participants' ratings that strongly favored the training program in terms of relevance to their work, comprehensiveness of discussion, clear presentation, interesting and interactive learning environment, appropriate use of audio-visual aids, and adequacy of time.

The "Assessment of Student Achievement" seminarworkshop was held in August, September, and October 2016 at a three-star hotel in Quezon City. Participants were composed of 27 faculty from Luzon, 47 from Vis-Min, and 29 from NCR $(n=98)$. This theme was chosen based on the feedback of participants during the 2015 training. The onehour inputs were on the basic principles of assessment in terms of what to assess (referring to the program outcomes stipulated in CMO 18), when to assess (diagnostic, formative, and summative assessments), and how to assess. This last topic introduced participants to the criteria in constructing assessment tools and the various steps in constructing selected response and constructed response written tests and practical examinations like the Objective Structure Clinical Examination (OSCE). Table 4 presents a summary of participants' ratings in terms of means and SDs. Figures show higher ratings compared to the 2015 results. Results further affirm the participants' strong appreciation because of the negatively skewed ratings and no variations in the median, Q1, Q3, and IQR values.

Due to the expressed identified needs of the faculty, APMC conducted two series of CPDs in 2017. The seminar-workshops on "Best Evidence Teaching Strategies" were conducted in April and twice in May 2017 with 99 participants. Again, this theme was chosen based on the recommendations of the 2016 participants. Resource persons introduced when and how to use technological pedagogical and content knowledge (TPACK), PBL, Case Discussion, Blended Learning, Mentoring, and Self-Directed Learning. Workshops and Plenaries were held to provide participants first-hand experiences in the planning and executing of these innovative teaching strategies.

Table 5 presents a summary of participants' ratings in terms of means and SDs. This series registered the lowest evaluation ratings compared to all seminar-workshops, even if the overall equivalents remained highly satisfactory. Participants appreciated the program as most relevant to their work (Mean=3.80), but they did not rate the rest of 
In-service Training Programs for the Medical Faculty

Table 3. Means, SDs, Medians, and Interquartile Range of Participants' Ratings on the 2015 Seminar-Workshop (number of respondents who accomplished the form, $n=91$ )

\begin{tabular}{lcccccc}
\multicolumn{1}{c}{ Constructs } & Mean $(\overline{\mathbf{x}})$ & SD & Median & Q1 & Q3 & IQR \\
Relevant to my work & 3.84 & 0.38 & 4 & 4 & 4 & 0 \\
Discussed comprehensively & 3.64 & 0.58 & 4 & 3 & 4 & 1 \\
Clearly presented & 3.62 & 0.58 & 4 & 3 & 4 & 1 \\
Interesting and interactive & 3.62 & 0.61 & 4 & 3 & 4 & 1 \\
Presented using appropriate visual aids & 3.59 & 0.64 & 4 & 3 & 4 & 1 \\
Given adequate time & 3.56 & 0.58 & 4 & 3 & 4 & 1 \\
\hline
\end{tabular}

Table 4. Means, SDs, Medians, and Interquartile Range of Participants' Ratings on the 2016 Seminar-Workshop $(n=94)$

\begin{tabular}{lcccccc}
\multicolumn{1}{c}{ Constructs } & Mean $(\overline{\mathbf{x}})$ & SD & Median & Q1 & Q3 & IQR \\
\hline Relevant to my work & 3.91 & 0.29 & 4 & 4 & 4 & 0 \\
Discussed comprehensively & 3.83 & 0.38 & 4 & 4 & 4 & 0 \\
Clearly presented & 3.83 & 0.38 & 4 & 4 & 4 & 0 \\
Interesting and interactive & 3.83 & 0.38 & 4 & 4 & 4 & 0 \\
Presented using appropriate visual aids & 3.82 & 0.39 & 4 & 4 & 4 & 0 \\
Given adequate time & 3.73 & 0.50 & 4 & 4 & 4 & 0 \\
\hline
\end{tabular}

Table 5. Means, SDs, Medians, and Interquartile Range of Participants' Ratings on the SeminarWorkshop on Best Evidence Teaching Strategies $(n=58)$

\begin{tabular}{lcccccc}
\multicolumn{1}{c}{ Constructs } & Mean $(\overline{\mathbf{x}})$ & SD & Median & Q1 & Q3 & IQR \\
Relevant to my work & 3.80 & 0.42 & 4 & 4 & 4 & 0 \\
Discussed comprehensively & 3.63 & 0.52 & 4 & 3 & 4 & 1 \\
Clearly presented & 3.65 & 0.53 & 4 & 3 & 4 & 1 \\
Interesting and interactive & 3.70 & 0.52 & 4 & 3 & 4 & 1 \\
Presented using appropriate visual aids & 3.63 & 0.55 & 4 & 3 & 4 & 1 \\
Given adequate time & 3.58 & 0.64 & 4 & 3 & 4 & 1 \\
\hline
\end{tabular}

the constructs the same way. The very nature of the program could explain this. More than fifty percent of all the training participants were Baby Boomers: those born from the 1950s until 1964. There were even participants who were more than 80 years old because the new medical schools have rehired them after their retirement. This subset of participants admitted that they are "technologically challenged" and try their best to connect and teach effectively with their very young learners, those belonging to the millennial learners. The divide between these generations of teachers and learners was covered in this seminar series. However, figures still show that the ratings are homogeneous and collectively shared by respondents based on the very low values of SDs, and almost no variations in the median, Q1, Q3, and IQR values.

The "Continuing Professional Development for Academic Executives of Medical Schools" was conducted in October and twice in November 2017. APMC conducted this in-service training program because of the need of the deans who admitted being challenged by the shift to OBE and the new roles expected of them as educational leaders and managers. These roles and standards were stipulated in CMO 18, 2016. A total of 99 participants were trained.
Participants were coached on constructing institutional vision, mission, and goals, aligning them with their own, and discussing the various changing landscapes that affect medical education. Participants in this program were all faculty administrators and were engaged in organizational problem analysis, planning, accreditation, and total quality management (TQM). Table 2 shows that participants in this program presented their organizational (tactical) plans using a log frame matrix. Many of the participants admitted during the plenary that they encountered this term for the first time.

Table 6 presents a summary of participants' ratings in terms of means and SDs. Like in previous seminar-workshops, mean ratings remained close to 4.00 with relevance getting the highest mean of 3.83 . The persistent construct with the lowest rating is the adequacy of time since the workshop and plenary requires the individual participant to present his/her actual outputs, and feedbacking usually extended beyond 5:00 pm. Compared to the previous programs, Table 6 shows the most variations in terms of median and Q1, Q3, and IQR values. These prove the participants' relatively varied ratings assumed to be influenced by their respective experience as faculty administrators. Participants in this program included 
Table 6. Means, SDs, Medians, and Interquartile Range of Participants' Ratings on the SeminarWorkshop on Continuing Professional Development for Academic Executives of Medical Schools $(n=81)$

\begin{tabular}{lcccccc}
\multicolumn{1}{c}{ Constructs } & Mean $(\overline{\mathbf{x}})$ & SD & Median & Q1 & Q3 & IQR \\
Relevant to my work & 3.83 & 0.37 & 4 & 4 & 4 & 0 \\
Discussed comprehensively & 3.74 & 0.46 & 4 & 4 & 4 & 0 \\
Clearly presented & 3.73 & 0.46 & 4 & 3 & 4 & 1 \\
Interesting and interactive & 3.75 & 0.44 & 4 & 4 & 4 & 0 \\
Presented using appropriate visual aids & 3.70 & 0.48 & 4 & 3 & 4 & 1 \\
Given adequate time & 3.68 & 0.50 & 4 & 3 & 4 & 1 \\
\hline
\end{tabular}

Table 7. Means, SDs, Medians, and Interquartile Range of Participants' Ratings on the SeminarWorkshop on Quality Assurance and Standard Setting $(n=77)$

\begin{tabular}{lcccccc}
\multicolumn{1}{c}{ Constructs } & Mean $(\overline{\mathbf{x}})$ & SD & Median & Q1 & Q3 & IQR \\
Relevant to my work & 3.84 & 0.37 & 4 & 4 & 4 & 0 \\
Discussed comprehensively & 3.62 & 0.50 & 4 & 3 & 4 & 1 \\
Clearly presented & 3.64 & 0.40 & 4 & 3 & 4 & 1 \\
Interesting and interactive & 3.67 & 0.48 & 4 & 3 & 4 & 1 \\
Presented using appropriate visual aids & 3.67 & 0.47 & 4 & 3 & 4 & 1 \\
Given adequate time & 3.58 & 0.51 & 4 & 3 & 4 & 1 \\
\hline
\end{tabular}

Table 8. Means, SDs, Medians, and Interquartile Range of Participants' Ratings on the SeminarWorkshop on Mentoring in Medical Schools ( $n=77$ )

\begin{tabular}{lcccccc}
\multicolumn{1}{c}{ Constructs } & Mean $(\overline{\mathbf{x}})$ & SD & Median & Q1 & Q3 & IQR \\
Relevant to my work & 3.92 & 0.26 & 4 & 4 & 4 & 0 \\
Discussed comprehensively & 3.84 & 0.37 & 4 & 4 & 4 & 0 \\
Clearly presented & 3.85 & 0.36 & 4 & 4 & 4 & 0 \\
Interesting and interactive & 3.88 & 0.33 & 4 & 4 & 4 & 0 \\
Presented using appropriate visual aids & 3.85 & 0.36 & 4 & 4 & 4 & 0 \\
Given adequate time & 3.83 & 0.37 & 4 & 4 & 4 & 0 \\
\hline
\end{tabular}

mostly the deans, associate deans, department chairs, college secretaries, and quality assurance personnel. This was the only program that included non-MD participants like those with degrees in Human Resource Management and TQM.

As a continuation of faculty-administrators' training, the "Seminar-Workshop on Quality Assurance and Standard Setting" was conducted three times in May 2018. This was the only in-service training conducted for one day and attended by 108 participants. Sessions featured discussions on quality assurance in medical education, analysis of participants' institutions using CHED's Institutional Sustainability Assessment (ISA) form, and development of formative and summative workplace-based assessment plans for students. Participants were a mix of faculty and those with administrative roles.

Table 7 presents a summary of participants' ratings in terms of means and SDs. Results show the same patterns of negatively skewed and homogeneous ratings, indicating a high level of appreciation.

The last in the 2018 seminars focused on "Mentoring in Medical Schools." This was conducted twice in October and once in November. There were 97 participants. This theme was especially conducted in response to the participant's previous recommendations alarmed with the increasing trend of mental health problems among medical students. Sessions included inputs on basic principles of mentoring, including the continuum of roles and skills of mentors, stages of mentoring, setting up, monitoring, and evaluating mentoring programs. The highlight of the program was the video demonstration of groups on the various mentoring scenarios. Participants were made especially conscious of their mentoring roles as they were primed for the APMC Conference focused on the theme "Mental Health of Medical Students" set for February 2019.

Table 8 presents a summary of participants' ratings in terms of means and SDs. Results show the same patterns of negatively skewed and homogeneous ratings, so the medians, Q1, Q3, and IQR were also obtained. Ratings indicate a high level of appreciation for the program. Compared to all the five other programs, this training generated the highest ratings across all constructs, including time adequacy. 


\section{QUAL Phase}

\section{Theme 1: Medical faculty becoming innovative}

Actual syllabi, instructional designs and resources, tests, and other assessment tools shared by participants were analyzed. Observations and notes on these resources were raised during the FGDs. The type of curriculum track being pursued by participants surfaced immediately. In all sessions, participants openly said: "PBL kasi kami" (We follow PBL), "COME kami" (referring to those following the communitybased medical education), "dati kaming competency-based pero ngayon ay OBE na" (we used to be competency-based but have shifted now to OBE). On the other hand, those who are still following the Flexnerian Curriculum quickly shared that they also used various teaching-learning (TL) strategies and assess learner achievement using workplacebased instruments instead of just written examinations. As

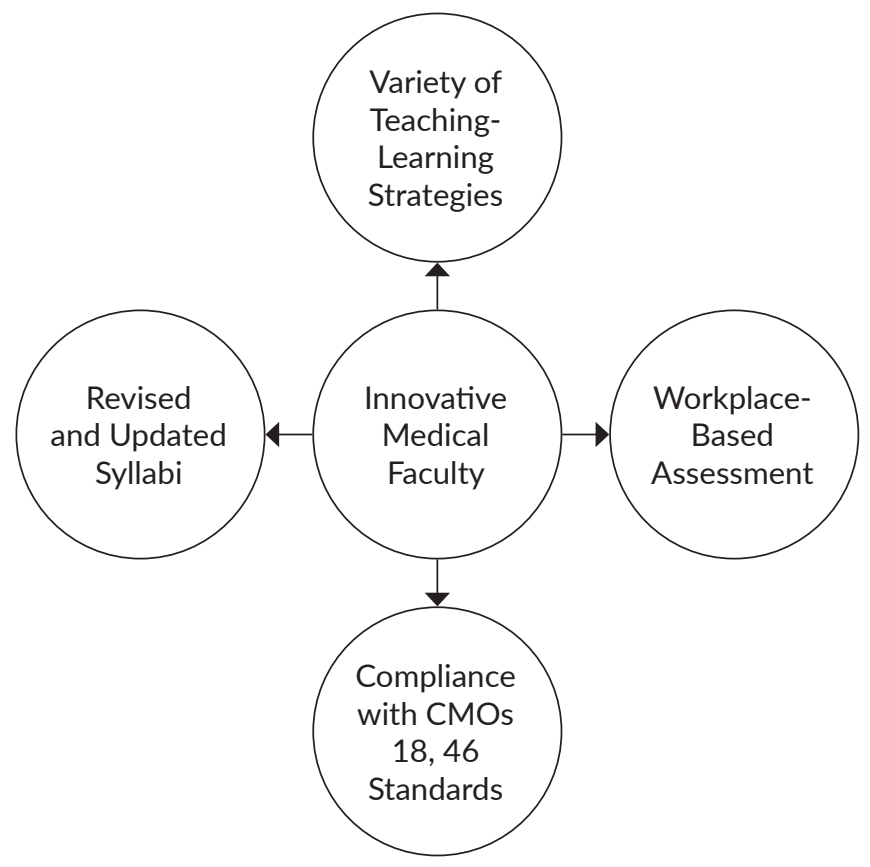

Figure 1. Joint Display of Medical Faculty Getting Innovative. the participants were quick in labeling themselves according to these curriculum designs, they demonstrated confidence in sharing how they were transitioning to full OBE. Their inputs in the FGDs, the selected instructional resources and assessment strategies reviewed pointed to the theme that medical schools are now pursuing innovative teachinglearning and assessment strategies. Figure 1 presents a joint display showing selected excerpts from the FGDs, distinct teaching and learning, and assessment strategies. Results also show that the method being used by the faculty are also the same standards required in CMO 18.

The most concrete indicators that the medical faculty are getting innovative include their regular updating of the syllabi in their courses. These documents reflect their schools' institutional vision, mission, goals, formulation of clear learning outcomes, subject matter, a variety of TL activities, and assessment instruments. Table 9 shows these elements in an excerpt instructional design from one medical school.

The documents reviewed also reveal that TL strategies are no longer generic in all courses but cognizant of the instructional settings. These delivery strategies are grouped according to these categories:

1. All types of lectures: classic, interactive, didactics, plenary presentations, question and answer, Socratic method, seminar-type

2. Small group teaching strategies: small group discussion, role play, buzz group, brainstorming, jigsaw puzzle, tutorials, focus group discussion, simulations and use of standardized patients, case-based discussions

3. Online strategies: flipped classroom, team-based learning, problem-based learning, use of learning management system, blended learning, evidence-based learning

4. Laboratory teaching strategies: practical exercises, orals, dissection, experiments, simulation of various laboratory equipment, use of models, skills building, case-based discussions

5. Clinical teaching strategies: rounds, bedside preceptorial, demonstration-return demonstration, clinical rotations in various settings, conferences, patient care

Table 9. Excerpts from a Biochemistry Syllabus

\begin{tabular}{|c|c|c|c|c|c|}
\hline $\begin{array}{l}\text { Topic and Learning } \\
\text { Outcomes }\end{array}$ & Topics & Time & Activities / Strategies & $\begin{array}{l}\text { Performance Indicators/ } \\
\text { Assessment Tools }\end{array}$ & Learning Resources \\
\hline \multicolumn{6}{|c|}{ Prelims, First Semester } \\
\hline $\begin{array}{l}\text { Determine the } \\
\text { biochemical } \\
\text { pathway or process } \\
\text { involved in a given } \\
\text { clinical scenario }\end{array}$ & $\begin{array}{l}\text { Amino Acids } \\
\text { Proteins } \\
\text { Enzymes } \\
\text { Bioenergetics } \\
\text { Biologic Oxidation } \\
\text { The Respiratory Chain and } \\
\text { Oxidative Phosphorylation } \\
\text { Citric Acid Cycle } \\
\text { Muscle }\end{array}$ & $\begin{array}{l}\text { Please } \\
\text { refer to } \\
\text { the Topic } \\
\text { Guide. }\end{array}$ & $\begin{array}{l}\text { Interactive lecture } \\
\text { Small group discussion } \\
\text { Problem-solving } \\
\text { Case-based learning (CBL) } \\
\text { Collaborative learning } \\
\text { Independent study }\end{array}$ & $\begin{array}{l}\text { Written examination } \\
\text { Scoring rubric for written } \\
\text { reports } \\
\text { Scoring rubric for oral } \\
\text { presentations }\end{array}$ & $\begin{array}{l}\text { Textbooks } \\
\text { Reference books } \\
\text { Computers } \\
\text { Internet sources } \\
\text { Multimedia projector } \\
\text { Videos } \\
\text { Chalkboard/ } \\
\text { Whiteboard }\end{array}$ \\
\hline
\end{tabular}

Acknowledgment to Medical School No. 19 for this Syllabus. Schools were coded. 
6. Teaching in the community: facilitating community meetings and organizations, family immersion, patient care, fieldwork, collaborative learning, interprofessional education, multidisciplinary approach

7. Individualized learning strategies: reflection, journaling, diary, concept mapping, retreats, learning contract, online learning

In terms of assessment strategies, the written assessment plans also indicate that the faculty members are already using formative and summative assessments. The groupings of their responses are presented according to the specific domain of learning being assessed. Identifying such domains is also identified as a clear sign of being innovative because it means the faculty members are already conscious of achieving the program outcomes in medicine beyond knowledge acquisition.

1. Focus of assessment: Knowledge from the recall of facts to creating, critical thinking, problem-solving

a. Formative assessment strategies: selected-response tests: multiple-choice questions (MCQ), matching type, true-false, constructed response tests: supply type (fill in the blanks), identification, essay, reflection papers, critical appraisals, case reports, oral recitation, case presentations

b. Summative Assessment: preliminary periodical tests, midterm examination, finals, research defense, graded oral presentations, portfolios, case reports, logs of procedures, comprehensive examination

2. Skills: motor skills, feeling, and language motor; clinical reasoning and judgment, evidence-based practice

a. Formative assessment: the accomplishment of procedures prescribed in laboratory manuals, practical and oral examinations, recitals, return demonstrations, role-playing, simulation, peer evaluations

b. Summative assessment: objective structured clinical examination (OSCE), Direct observation of Procedural Skills (DOPS), Mini-Clinical Examination (MiniCEX), Process and product practical examinations, Oral reválida

3. Attitudes, deportment

a. Formative: Journals, logs, diaries, peer evaluations, oral and practical examinations

b. Summative: OSCE, DOPS, Mini-CEX, Group evaluations, Multi-source feedback, Patient satisfaction survey, Oral reválida

4. Self-directed learning

a. Formative: Reflection papers, logs, journals, and diaries, Critical appraisal of literature, Journal report

b. Summative: Portfolio, Individual projects like video production, infographics, infomercial, recital, exhibits
Selected FGD inputs are presented below, indicating participants' consistency to welcome APMC's workshops, especially in capacitating them to transition to $\mathrm{OBE}$, embracing innovative teaching and assessment strategies:

1. I have the privilege of attending those (APMC) trainings... We are going to follow the standards set by $\mathrm{OBE}$ starting with $\mathrm{OBE}$ syllabus

2. Proficiency in Delivery? For instance, in the workshop on instructional design, we get a deeper understanding of CMO 18, how they engage millennial students, how to explain, question, conduct small groups, like in PBL, how to make a case, then simulate, then comment. The outputs of students remarkably improved.

3. Before, our students did not pass our examinations. But because of the changes we are making, they are now passing. We have not fully implemented all the innovative strategies but we already use SGD, formulate objectives, now it's working. I head the curriculum committee and I told my colleagues: Let's do something and we are all excited. A long way to go but we are confident that OBE will make things better.

4. Yung changes nakikita talaga namin. Very aggressive like assessment or yung realignment $n g$ objectives... So ngayon we are making improvement. Nakikita naming kasi nuon binde pumapasa mga students naming sa exam sa IM for example but because of the changes nakikita naming pumapasa na yung mga IM. (We see the changes of matching objectives and outcomes with assessment; our internal medicine students are now passing our exams).

5. Nadedeliver $n g$ OBE graduates yung gusto $n g$ work, kasi they perform na alam ang rationale. Yung OBE assessment part will shape you. Basta don't forget the LOTS (lower order thinking skills) going to the HOTS (higher order thinking skills). (Graduates of OBE are able to perform according to expectations because they know the rationale of a lesson from the LOTS to the HOTS).

Figure 1 cites that the theme is also supported by the faculty's compliance with CHED memorandum orders. Their willingness and institutional decisions to transition to OBE mean compliance with CMO 46 Sections 3.1, 3.1.1, and 3.1.2, where teachers were asked to advocate for learnercentered classes, changing teachers' roles to being catalysts and facilitators of learning. The inputs of participants in the FGDs also provided evidence of their compliance with Sections 4 (on teaching towards the program outcomes), 10 (formulating syllabi with integrated concepts and topics instead of just following the outlines of topics given in textbooks), 13.1 to 13.5 (where faculty members should meet certain standards, especially in completing CPD to enhance their andragogic competencies, and 18.1 to 18.8 where faculty members are required to update their courses regularly, adopt innovative TL Strategies and adopt OBE assessment for student achievement. 
On the other hand, it has been earlier cited that among the CPD programs conducted, the one that required TPACK and Blended Learning was rated the lowest. Participants clarified in the FGD that:

1. Personally, I didn't know flipped classroom, how to facilitate it. Even if you want to do it, if you are not adept, it can be intimidating. Or lecture online but I am not sure if students will appreciate it or students will just say I didn't want to go to school.

2. We use the old method: lecture type and perhaps the preceptorship style of learning. Now we need to teach other than lecturing; divide the class in small groups, engage students in case discussion, plenary, online learning, and make use of learning management system and computer-based library collections

3. Technology enhancement, simulation; bindi lahat ng doctors ay marunong magturo, or techie (Not all doctors know how to teach or can use modern technology in teaching).

Theme 2: College officials facing the $21^{\text {st }}$ century challenges of medical education

The inputs of participants in the FGDs were straightforward and intense at some points. Out of the 33 discussants, four deans (two from Luzon, NCR, and Mindanao) repeatedly expressed the most challenging tasks they face as administrators. These tasks are grouped in the joint display of Figure 2. Paramount is the pressure for graduates to pass the state board examination that also serves as their schools' marketing strategy. FGD participants appreciated the exercise using CHED's Internal

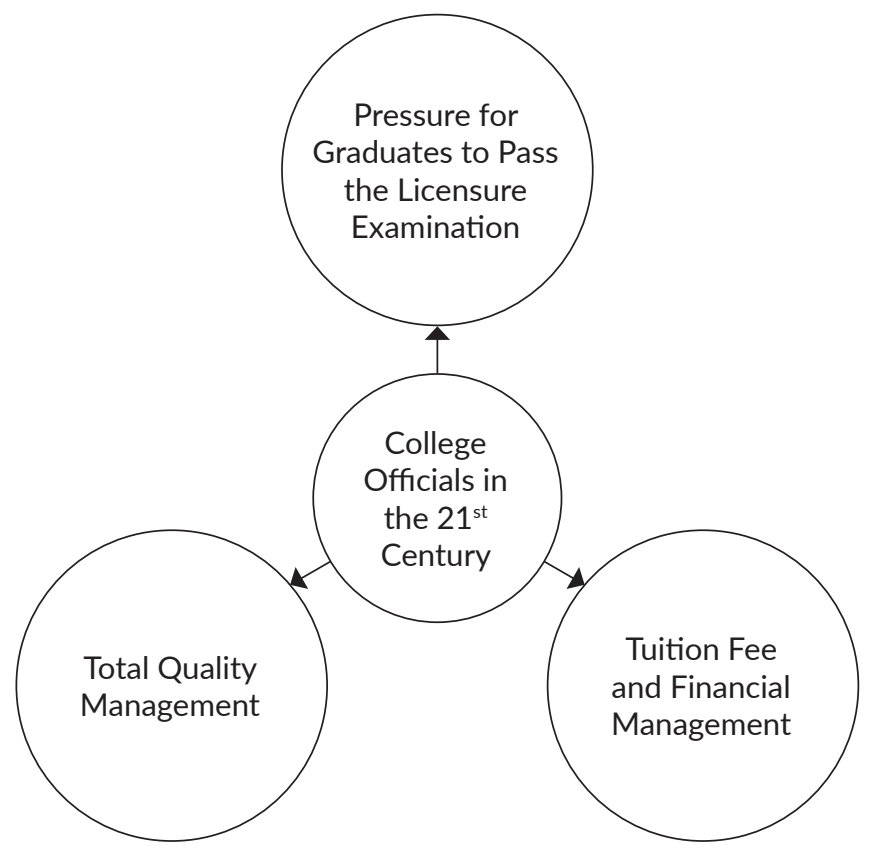

Figure 2. Joint Display of College of Medicine Officials Facing the $21^{\text {st }}$ Century.
Sustainability Assessment tool, where they could make an honest-to-goodness evaluation of their institutions' standing. They were all aware that passing the licensure examination is an indicator of their quality that is part of the required document in applying for accreditation.

On the other hand, the recruitment of students is synonymous with income and financial stability. However, participants explained that imposing the selection criteria set in CMO 18 is sometimes challenging to meet, especially for private medical schools. They notably referred to a percentile rank of $\geq 40$ in the National Medical Admission Test (NMAT). College administrators admitted that there were instances that they admitted students whose NMAT were lower than 40 to keep the finances of the school stable. As of 2018, there was a moratorium for medical schools to implement this NMAT score.

Regarding TQM, the concerns of college officials include the required accreditation, especially with the Philippine Accrediting Association of State Colleges and Universities (PAASCU). These officials are aware that by 2024, the United States Educational Commission for Foreign Medical Graduates (ECFMG) will require graduates of foreign medical schools to present their medical school's accreditation certificates before they are allowed to take the United States Medical Licensure Examination (USMLE) and qualify for residency training in the US. As of December 2019, out of 51 schools, 29 (47.50 percent) were still not accredited. There were eight (13.1\%) accredited as Level 1 with the PAASCU, three for Levels 2 and 3, and two schools with Level 4 Accreditation. Out of these two, the only state university has also been recently certified Level 4 in the AUN Quality Assurance System.

Integral to the TQM is the persistent challenge of recruiting competent faculty members. Participants shared in the FGD that:

1. One of the burning issues is to encourage professors of medicine or medical doctors to go to the academe or teaching professions because we all know doctors go back to the province not to teach but to earn a living, and this refers to clinical practice.

2. Mahirap maghanap $n g$ faculty $n a$ qualified $s a$ qualifications ng CMO kasi unang-una part-time lang sila at kung minsan ayaw pa nila magturo; hours lang ang gusto. If you want to teach clinical subjects, you must be a specialist sa government kasi salary 24 eh compared sa amin, salary in private not that high. (It is difficult to recruit faculty who meet the qualifications in $\mathrm{CMO}$ 18. In the first place, they only want to teach part-time, for a few hours. Salary in government is higher than in private institutions).

3. Maybe APMC can propose to implement a standard salary scale for medical teachers. Salaries of faculty are markedly different between those in NCR and the provinces, the public and private, and those that are teaching full- or part-time, basic and clinical sciences. 
Regarding the overall perspectives on attending the APMC in-service training programs, the dean and her two other colleagues from Medical School No. 15 wrote feedback, "Thank you, APMC, and dear facilitators. You have provided us the light and the sunshine so that we can perform our duties competently and enjoyably."

\section{DISCUSSION}

APMC responds to the global call for a transformative scale-up of medical education. One of its initiatives is conducting a series of in-service training programs to capacitate faculty members to meet the evolving standards of medical education. From 2015 to 2018, the series of training programs were designed to equip the faculty to perform their professional roles as instructional designers, facilitators of learning, assessors of student achievement, and educational leaders and managers. The six seminarworkshops conducted for the medical faculty members in four years reflect outcome-based education instructional design. All the programs articulated the outcomes expected from participants, required them to turn in real outputs that are used in their classes, provided for them not just takehome knowledge and principles but also opportunities to practice various skills, and access to all instructional resources they can use when they return to their institutions. In a nutshell, these CPD programs capture what Spady described as the 4Ds referring to direction, design, delivery, and real learning documentation. ${ }^{17}$ The four Ds are all formulated only after the outcomes in each training were articulated. Table 2 presents all these OBE elements integral in all the seminar-workshops.

However, aside from describing the training programs themselves and explaining how participants perceived them, this study also presents the primary measures of social accountability that APMC can claim in these training programs. The World Health Organization defines social accountability of medical schools as "the obligation to direct their education, research, and service of activities towards addressing the priority health concerns of the community, the region, nation or both that they have the mandate to serve." ${ }^{18}$ In the APMC context, its priority concerns refer to preparing the medical faculty to meet the basic standards of teaching to produce graduates who will be accorded the second to the highest level of educational qualifications in the PQF (equivalent to Level 7). As mentioned earlier, social accountability indicators include quality, equity, relevance, and cost-effectiveness.

Quality to APMC refers to capacitating the medical faculty on the basic principles and applications of instructional designing, facilitating learning, managing various instructional settings, constructing valid and reliable tests, leading, and managing medical schools. Steinert et al. conducted a systematic review of faculty development programs that capacitated teachers on various facilitating skills. They used Kirkpatrick's Levels 1-4 program evaluation model in determining if such programs can translate to better teaching. The study reported that even within short periods, faculty members could improve their skills in selected roles like planning, teaching, and assessing learner achievement. ${ }^{19}$

Building quality among medical faculty should not just be for a limited few but should be made available to all faculty members. APMC demonstrated equity by conducting three batches of training programs, especially for faculty members of medical schools in Luzon, NCR, and Visayas-Mindanao groups. Relevance is the measure by which priorities have been set in an action program accepting that the most critical problems are tackled first. ${ }^{20}$ Since 2015 when the first OBE seminar-workshop was conducted, APMC has always solicited feedback from all participants on their competency gaps. The feedbacks serve as bases in planning the succeeding in-service training programs. The arrangement of the six training programs in four years shows the expressed needs that the medical faculty wanted to address according to their order of priority. Finally, given the budget restrictions for faculty development programs, APMC conducted the seminar-workshop series at minimal costs. The last indicator of social accountability is cost-effectiveness, and APMC achieved this by charging minimal registration fees from participants. The programs were carried out at a three-star hotel to ensure that participants from the regions can afford a 2-night accommodation aside from their travel expenses.

\section{Scope and Limitations}

Participants in this study were limited only to those faculty and medical schools that participated in the in-service training programs of APMC. Although they represented the four prominent geographical locations of the medical schools in Luzon, Visayas, Mindanao, and the National Capital Region, there were still six out of 51 medical schools that could not participate in this study.

The study's findings were limited to perceptions and copies of actual instructional designs and training outputs of participants. No real observations and additional data collection procedures were done to verify that the faculty are carrying out those included in the design in their respective classes.

\section{CONCLUSION}

The APMC conducted six in-service training programs that prepared medical faculty to perform their roles as facilitators of learning, assessors of learning achievement, and educational leaders and managers. These continuing professional development programs conducted from 20152018 were perceived most favorably by medical faculty and school administrators.

The respondents' perceptions reveal that the in-service training programs have made them comfortable using innovative teaching-learning strategies and workplace-based 
assessment of learner achievement. Participants are also taking on the challenge of the changing landscape of leading and managing medical schools.

APMC responds to the global call for transformative learning by capacitating its primary stakeholders: the medical faculty. This initiative also reflects the institution's social accountability as the CPD programs contribute to promoting quality, equity, relevance, and cost-effectiveness.

\section{Statement of Authorship}

Prof. Erlyn A. Sana, developed the research concept and design; reviewed literature, wrote the methodology, conducted the data acquisition, analysis, and interpretation; drafted, revised, and finalized the manuscript, agreed to be accountable for all aspects of the work.

Dr. Melflor A. Atienza, reviewed literature, helped in writing the proposal, conducted the data acquisition, analysis, and interpretation; drafted, revised, and helped finalize the manuscript, agreed to be accountable for all aspects of the work.

Dr. Ramon L. Arcadio, Dr. Enrico B. Gruet, Dr. Norman C. Gonzaga, Dr. Remedios D. Chan, and Dr. Agnes D. Mejia, approved the research concept and design, helped in writing the proposal, and advised the group in the analysis, and interpretation; drafted, revised, and helped finalize the manuscript, agreed to be accountable for all aspects of the work.

All authors participated in data collection and analysis, and approved the final version submitted.

\section{Author Disclosure}

All authors declared no conflicts of interest.

\section{Funding Source}

This is a study commissioned by the Association of Philippine Medical Colleges, Inc.

\section{REFERENCES}

1. Association of Philippine Medical Colleges [Internet]. [cited: 2019 August 1]. Vision and mission. Available from: webv2.apmcf-ph.net/ apmc_wp/ about-apmc/vision-and-mission/

2. Commission on Higher Education [Internet]. CHED Memorandum Order 46 Policy-standard to enhance quality assurance (QA) in Philippine higher education through an outcomes-based and typologybased QA. Quezon City: Commission on Higher Education. 2012. [cited: 2019 August 15]. Available from: https://ched.gov.ph/cmo46-s-2012/
3. Commission on Higher Education [Internet]. CMO 18 s.2016 Policies, standards, and guidelines for the doctor of medicine program. Quezon City: Commission on Higher Education. 2016. [cited: 2018 September 12]. Available from: https://ched.gov.ph/wp-content/ uploads/2017/10/CMO-18-s.-2016.pdf

4. Republic of the Philippines. Republic Act 10912: The Continuing Professional Development Act. Manila: Senate of the Republic of the Philippines. 2016.

5. Frenk J, Chen L, Bhutta ZA. Health professionals for a new century: Transforming education to strengthen health systems in an interdependent world. The Lancet. 2010:1-116.

6. Global consensus for social accountability of medical schools. [Internet]. [cited: 2010 Dec]. Available from: www.healthsocialaccountability.org

7. Irby D, Cooke M, O'Brien B. (2010). Calls for reform of medical education by the Carnegie Foundation for the advancement of teaching: 1910 and 2010. Academic Medicine. 2010.

8. Cuff PA. Envisioning the future of health professions education. Washington DC: National Academies Press. 2016.

9. Dans AML. Health Education and Health Care System Reform. Current status of basic medical education in the Philippines 2016. Taguig City: National Academy of Science and Technology, Association of Philippine Medical Colleges. 2016.

10. Philippine Department of Health [Internet]. [cited: 2019 August 5]. Available from: https://data.gov.ph/agencies/department-health

11. World Health Organization. Transformative scale up of health professional education. Geneva: Health Systems and Services, WHO. 2011.

12. Subedi D. Explanatory sequential mixed method design as the third research community of knowledge claim. American Journal of Educational Research. 2016 January;4(7):570-577. DOI: 10.12691/ education-4-7-10.

13. Guetterman TC, Fetters MD, Creswell JW. Integrating quantitative and qualitative results in health science mixed methods research through joint displays. Ann Fam Med. 2015 Nov;13(6):554-561. DOI: 10.1370/afm.1865.

14. Creswell J, Hirose M. Mixed methods and survey research in family medicine and community health. Fam Med Com Health 2019:7:e000086.DOI:10.1136/fmch-2018-000086.

15. Atienza M. The eclectic nature of Philippine medical curricula. Current status of basic medical education in the Philippines 2016. Taguig City: National Academy of Science and Technology, Association of Philippine Medical Colleges. 2016.

16. Measures of variability: the range, inter-quartile range and standard deviation. [Internet]. [cited: 2020 August 5]. Available from: https:// www2.le.ac.uk/offices/ld/all-resources/numerical-data/variability

17. Spady W. Outcome-based education: Critical issues and answers. Philadelphia: American Association of School Administrators. 1994.

18. Rourke J. Social accountability in theory and practice. Ann Fam Med 2006 Sep; 4 (Suppl 1): S45-S48; DOI: 10.1370/afm.559.

19. Steinert Y, Mann K, Centeno A. A systematic review of faculty development initiatives designed to improve teaching effectiveness in medical education: BEME Guide No. 8. Med Teach. 2006 Sep; 28(6):497-526. DOI:10.1080/01421590600902976.

20. Boelen, C. Towards unity for health: Challenges and opportunities for partnership in health and development. Geneva: WHO. 2000. 